\title{
Effect of Different Storage Period on Lactic Acid Bacterias from Goji Yogurt and Goji Yogurt with Honey
}

\author{
Ancuța M. ROTAR, Cristina SEMENIUC*, Florina BUNGHEZ, Mirela JIMBOREAN, Carmen POP \\ University of Agricultural Sciences and Veterinary Medicine, Faculty of Food and Science Technology, 3-5 \\ Mănăştur street, Cluj-Napoca, România \\ *Corresponding author, e-mail: cristina.semeniuc@usamvcluj.ro
}

Bulletin UASVM Food Science and Technology 71(1) / 2014

ISSN-L 2344-2344; Print ISSN 2344-2344; Electronic ISSN 2344-5300

\begin{abstract}
Lactic acid bacterias (LAB: Streptococcus thermophilus-ST, Lactobacillus bulgaricus-LB) are well known in the food technology area for their ability to produce lactic acid (LA) from carbohydrates throught fermentation. In case of goji yogurt the interaction between the two species of LAB has influence on the fermentation period and LA quantity. LAB's are widely used in the food industry because their growth in the dairy products lowers the carbohydrate content, they can also drop the $\mathrm{pH}$ values under 4.0, values were common pathogens are inhibited, and because of all these properties they are capable to prolong the shelf life. The present study aims to observe the evolution of LAB's - ST and LB, from goji yogurt (7\%) (A) and goji yogurt (7\%) with honey (B) during the shelf life in corelation with other physico-chemical properties such as sugar content, fat content and dry matter. The samples for the evaluation were taken in the first day of storage, at the middle of storage period and in the last day of storage.
\end{abstract}

Keywords: goji yogurt, lactic acid bacteria's, storage period, quality, fermented dairy products, optimal concentration

Introduction. Lactic acid bacterias (LAB: Streptococcus thermophilus-ST, Lactobacillus bulgaricus-LB) are well known in the food technology area for their ability to produce lactic acid (LA) from carbohydrates throught fermentation. In case of goji yogurt the interaction between the two species of LAB has influence on the fermentation period and LA quantity. LAB's are widely used in the food industry because their growth in the dairy products lowers the carbohydrate content, they can also drop the $\mathrm{pH}$ values under 4.0 , values were common pathogens are inhibited, and because of all these properties they are capable to prolong the shelf life.

Aim. The present study aims to observe the evolution of LAB's - ST and LB, from goji yogurt $(7 \%)(\mathrm{A})$ and goji yogurt (7\%) with honey (B) during the shelf life in corelation with other physico-chemical properties such as sugar content, fat content and dry matter. The samples for the evaluation were taken in the first day of storage, at the middle of storage period and in the last day of storage.

Materials and methods. The yogurt was obtained by fermentation and at the end of the process goji $(7 \%)$ and honey was added. The yogurt samples were sevenfold diluted and then placed on MRS agar, incubated under anaerobic condition $72 \mathrm{~h}$ at $37^{\circ} \mathrm{C}$ for Lactobacillus bulgaricus, and on M17 agar, incubated under anaerobic condition at $37^{\circ} \mathrm{C}$ for $48 \mathrm{~h}$ in case of Streptococcus thermophilus. After the incubation period the colonies were counted (10-300 UFC/ml) and the confirmation was made using specific tests (Gram afinity, colony aspect and catalaze + ).

Results. In the first day of storage the values for sample A were: $\mathrm{ST}=2,76 \times 10^{8} \mathrm{UFC} / \mathrm{ml}, \mathrm{LB}=2,6$ $\mathrm{X} 10^{8} \mathrm{UFC} / \mathrm{ml}$ and for sample $\mathrm{B}, \mathrm{ST}=2,0 \times 10^{7}$ $\mathrm{UFC} / \mathrm{ml}$ and $\mathrm{LB}=1,0 \times 10^{8} \mathrm{UFC} / \mathrm{ml}$. At the middle of the storage period the in case of sample $B$ the 
ST increased $\left(1,89 \mathrm{X} 10^{8} \mathrm{UFC} / \mathrm{ml}\right)$ while LB had a significant decrease $\left(1,09 \times 10^{6} \mathrm{UFC} / \mathrm{ml}\right)$. In case of sample A the ST decreased at half $(1,86 \mathrm{X}$ $10^{7} \mathrm{UFC} / \mathrm{ml}$ ) while LB was $2,04 \mathrm{X} 10^{7} \mathrm{UFC} / \mathrm{ml}$. It was interesting to observe that at the end of the storage in case of product A the levels of ST $(2,02 \mathrm{X}$ $\left.10^{7} \mathrm{UFC} / \mathrm{ml}\right)$ and $\mathrm{LB}\left(2,0 \times 10^{7} \mathrm{UFC} / \mathrm{ml}\right)$ remained approximatively the same. In case of product $B$ the levels of ST $\left(2,3 \times 10^{5} \mathrm{UFC} / \mathrm{ml}\right)$ and LB $\left(1,84 \times 10^{5}\right.$ $\mathrm{UFC} / \mathrm{ml}$ ) registered a significant decrease.

According to Bondia-Pons et al., (2014) the mainly soluble constituents of goji berries are the saccharides, phenols, organic acids and carotenoids (zeaxanthin).

These compounds are proven to selectively stimulate or suppress the bacterial population dynamics by their ability to hyperacidifiate the bacterial membrane, and precipitate the membrane proteins (Carolina Cueva et al., (2010).

In case of product $A$ the values of LB and ST remained approximatively at the same levels as at the middle of the storage period. The phenomena can be explained by the fact that adding goji to the final product caused a stimulation of the bacterial population from yogurt. The stimulents in this case were the phenolic compounds present in goji fruits. Same observations were made by Carolina Cueva et al., (2010).

Ranadheera et al., (2012) also observed that the addition of fruit juices into yogurt supported the viability of LB and ST during storage period compared with in plain yogurts.

The fluctuation of ST and LB from product B can be explained by the presence of honey in the product. In this case the large quantity of saccharides and the phenolic compounds from goji inhibited the growth of LB and ST. So the saccharides affected the osmotic pressure at the membrane level, destabilizing the membrane proteins, affecting the electron transfer and inhibit the bacterial metabolism. Same results were observed by Michael et al., 2010 and Shori and Baba (2012).

Another explanation should be given by the low stability of the culture in the fermented stage of the dairy product. This behaviour can be explained by the fact that the viable germs were inhibited by the presence of other microorganisms such as Enterobacteriaceae or yeasts and molds.

Conclusions. In order to maintain the number of viable cells at a concentrațion of $10^{6} \mathrm{UFC} / \mathrm{ml}$ (needed concentration in order to be qualified as a probiotic dairy product with health benefits upon the human organism).

We recommend that in order to maintain the minimum therapeutic level of LB and ST the jogurts should be enriched with fruits, but if the enrichement is done we do not recommend the addition of other products that could increase the saccharides levels of the final product.

\section{REFERENCES:}

1. Bondia-Pons, I. et al. (2014). Metabolic profiling of Goji berry extracts for discrimination of geographical origin by non-targeted liquid chromatography coupled to quadrupole time-of-flight mass spectrometry, Food Research International, Article in press

2. Cueva, C. et al. (2010). Antimicrobial activity of phenolic acids against commensal, probiotic and pathogenic bacteria, Research in Microbiology 161:372- 382

3. Michael, et al. (2010). Impact of a plant extract on the viability of Lactobacillus delbrueckii ssp. bulgaricus and Streptococcus thermophilus in nonfat yogurt, International Dairy Journal, 20(10):665-672.

4. Shori and Baba (2012). Viability of lactic acid bacteria and sensory evaluation in Cinnamomum verum and Allium sativum-bio-yogurts made from camel and cow milk, Journal of the Association of Arab Universities for Basic and Applied Sciences, 11: 50-55

5. Ranadheera, et al. (2012). Probiotic viability and physicochemical and sensory properties of plain and stirred fruit yogurts made from goat's milk, Food Chemistry, 135: 1411-1418. 